International Research Journal of Management, IT \& Social Sciences
Available online at https://sloap.org/journals/index.php/irjmis/
Vol. 9 No. 1, January 2022, pages: 10-18
ISSN: 2395-7492
https://doi.org/10.21744/irjmis.v9n1.1973

\title{
Project-Based Learning and its Contribution in Virtual Education
}

\author{
Jacqueline Aracely Arteaga Guerrero ${ }^{\text {a }}$ \\ José Atilio Murillo Moreira ${ }^{b}$ \\ María José Zambrano Zambrano ${ }^{\mathrm{c}}$ \\ Fernando Eduardo Cornejo Rivas ${ }^{\text {d }}$ \\ Marilyn Lidia Basurto Pilligua ${ }^{\mathrm{e}}$
}

Article history:

Submitted: 27 September 2021

Revised: 18 October 2021

Accepted: 09 November 2021

\section{Keywords:}

active methodologies; collaboration; pandemic; training; virtuality;

\begin{abstract}
At the present time, teaching is going through an experience at a global level, due to the COVID-19 pandemic. Students experienced a new way of learning, because of the health emergency; In this period, project-based learning was introduced as a contribution to virtual education, a methodology that was applied in the Sebastián Muñoz Educational Unit of the San Sebastián Parish of the Pichincha canton. The purpose of this work is to carry out an analysis of the contribution that this methodological strategy has had on high school students. The criterion that is intended to show is the marked acceptance that this significant learning has had, through a detailed analysis, starting from the management of the ordinary use platform Microsoft teams with which there is direct communication in the educational community. The qualitative method is proposed based on interpreting the data obtained from the objective set, using a direct survey of students and teachers. It was obtained as a result that the schoolchildren who make use of technological tools are precisely those who have efficient connectivity and that the educators who work the most applying the studied methodology are those who adequately handle the technological elements.
\end{abstract}

International research journal of management, IT and social sciences (C) 2022. This is an open access article under the CC BY-NC-ND license (https://creativecommons.org/licenses/by-nc-nd/4.0/).

Corresponding author:

Jacqueline Aracely Arteaga Guerrero, Pontificia Universidad Católica del Ecuador, Extensión Manabí, Portoviejo, Ecuador.

Email address: jarteaga9864@ pucesm.edu.ec

a Pontificia Universidad Católica del Ecuador, Extensión Manabí, Portoviejo, Ecuador

b Pontificia Universidad Católica del Ecuador, Extensión Manabí, Portoviejo, Ecuador

Pontificia Universidad Católica del Ecuador, Extensión Manabí, Portoviejo, Ecuador

d Pontificia Universidad Católica del Ecuador, Extensión Manabí, Portoviejo, Ecuador Pontificia Universidad Católica del Ecuador, Extensión Manabí, Portoviejo, Ecuador 


\section{Introduction}

Based on the analysis of the bibliographic review, this article aims to show the reader how Project Based Learning (PBL) has evolved, considering the globalization of technology and the application of active methodologies implemented in education.The PBL methodology is a research strategy that may not be known to some educators; However, its use is already in common use, although it has been criticized by several authors Bottle Nicolás \& Ramos Ramos (2019), others have recommended it because the results obtained have been satisfactory Solís \& Tacuri (2021), because it favors integration of the students. Its use is born with the presence of information technologies, as a technological tool that has the characteristics of shortening time and processes. The technological revolution has favored education on a large scale, by offering a variety of techniques that facilitate communication and the insertion of all kinds of educational projects.

Some authors mention that for decades teaching-learning strategies have already been used in many countries Borbor \& Suárez (2021), especially in developed countries that have chosen to face the demands of the educational system, with the purpose of equip students with skills and abilities. The advances that education and science currently have in countries such as Finland are recognized with a high acceptance range for their quality in teaching, where the PBL methodology is applied. Currently this is already part of the study program in most educational institutions in Ecuador, especially in private educational units. There is research on the PBL methodology, which shows the advantages it offers as a methodology, in this regard Escobar \& Lewin (2018), in their critical analysis they mention that learning favors indigenous communities, strengthening critical and reflective thinking in natives of the most vulnerable areas of the Amazon, where they use the application of this methodology as a knowledge facilitating strategy. The PBL is a methodological strategy on which the teacher proposes ideas through projects that the student develops, this strategy starts from a programmed design and is applied in practice with the purpose of generating new, investigative, cooperative and autonomous knowledge, in where the resolution is proposed as a challenge and the construction of a product that is presented to the educational community reflecting the work done.

\section{Materials and Methods}

This research was based on the qualitative method because data obtained from other PBL applications in different settings were interpreted. A survey was used as a support technique for the collection of information from the students of the Sebastián Muñoz Educational Unit, the sample corresponded to 100 high school students, with the purpose of knowing the contribution that the BPL had in virtual education, considering that it was an institution in the rural area. The applied survey contained closed questions, aimed at knowing the application of the strategy by the teachers, the effectiveness of the methodology and the level of academic performance of the students; In addition, it was complemented with a descriptive analysis of the data, through the values in percentages to later carry out the interpretation of the results (Sudarmo, 2020; Rayuwati, 2020).

\section{Results and Discussions}

PBL is one of the active methodologies used to improve the teaching-learning process, it is among the 8 methodological techniques that can be applied by teachers in the 21 st century (Larmer \& Mergendoller, nd), it is a new way that the teacher has an opportunity to promote knowledge in students. At its core, PBL enables students to acquire knowledge and key competencies through the development of projects that respond to real-life problems. The objective is to enhance their autonomy and make them the protagonist of their own learning process. Each group of students has to plan, structure, execute and present the product that must answer the chosen guiding question. For their part, the teacher has the responsibility of guiding and supporting the students throughout the entire project. This methodology was applied through an analysis in virtual education, in the students of the Sebastián Muñoz Educational Unit of the San Sebastián parish, Pichincha canton, school period 2021 - 2022, as was applied by other authors in the province of Manabí as a innovative proposal for the local educational system (López Miller, 2016).

Guerrero, J. A. A., Moreira, J. A. M., Zambrano, M. J. Z., Rivas, F. E. C., \& Pilligua, M. L. B. (2022). Project-based learning and its contribution in virtual education. International Research Journal of Management, IT and Social Sciences, 9(1), 10-18. https://doi.org/10.21744/irjmis.v9n1.1973 


\section{Project based learning}

Several authors consider that virtual education is a study modality that emerged in many educational sectors as a result of the health emergency caused by COVID 19, however, other sectors were affected by poor connectivity and the lack of preparation of teachers in the use of novel strategies, in order to attract the attention of students (Pari et al., 2021). These authors state that one of the strategies used to make student participation active was the use of PBL, a strategy that made it possible to put aside the boredom of many students and focus them on fulfilling a goal or purpose. The BPL is a learning methodology in which students become active protagonists of their work, where teachers complement education with their guidance and advice Leon et al. (2019), they consider that this strategy allows them to achieve Students become autonomous managers of learning and teachers fulfill their important role by serving as instructor mediator of the processes to generate knowledge. This strategy that emerged from active methodologies favors the teaching-learning process, achieving significant learning by developing activities in a conscious way (Mizrahi, 1984; Anastakis et al., 1999).

In this way, it can be understood that student participation is strengthened and usable resources are promoted in order to improve the understanding of what is planned, without neglecting the reality that many sectors have scarce technological resources, which causes some lags in The education. Currently, there are many work strategies to generate knowledge; However, there is a controversy due to the lack of information in many social sectors, especially in education Pachay-López \& Rodríguez-Gámez (2021), they comment that the health situation that has been experienced since 2020, allowed the evolution of technology and new ways of teaching, however, consider that the adverse effects that have occurred not only correspond specifically to health conditions, notable economic and social problems also arose in each place, thus, education was seriously affected, on the all in critical sectors, this allowed school dropouts to occur due to lack of accessibility to technological means, reflecting educational instability and a marked decrease in access to information (Leenders et al., 2003; Mesmer-Magnus et al., 2011).

The contents, resources, processes and results are part of an organization that is elaborated by the educator through planning, which requires achieving the purpose to show when the students have acquired and developed the skills and abilities Carbonnel et al. (2019), where learners will not only be recipients of information, but will also assimilate learning. Working with this methodology establishes the capacities of critical reasoning and metacognition; This is how Sagardia et al. (2020), state that the burden on the student of the cognitive activities of memorizing tasks, or exams with nonsense questions that once marked, is forgotten, decreases; PBL provides students with work done with their own will, opinion and emotions of well-being. It is considered essential that the project awakens motivation, ingenuity, creativity and intrinsic stimulation in students, as it must also be adapted to their needs and be directed to them (MuñozRepiso \& Gómez-Pablos, 2017). All research presented by those involved in a project emphasizes that students discover their own purpose and generate discipline in a didactic environment (Moya, 2017; Gámiz-Sánchez, 2017).

By applying the PBL, it is possible that students develop different capacities such as communicative competence where they forge their analysis and study skills of texts in different formats; in strategic competence, the learner is able to work in a systematic way, with a fixed vision within reach of the objectives, either alone or with a work team. The interpersonal competence that allows the person involved to make decisions that will lead to the development of their project, doing it with care and creativity; in addition to psychophysiological competence, which induces autonomous work as well as the use of short-, medium- and long-term memory. For several years, Ecuador has been undergoing changes in terms of education, emerging pedagogical and educational models that take into consideration the standards of quality and excellence, which is the goal proposed by all those involved in the national educational system; Furthermore, work has been done on the possible implementation of the PBL, thinking about the improvement of the teaching-learning process. It should be taken into account that any change takes time, but sometimes resistance, specifically when it comes to implementing these new models of education and even more so if they have a connection with technology (Borja \& López, 2017).

The BPL is a methodology that consists of the elaboration of a project thinking about the work group and the reality of the environment in which it works; Furthermore, this new program is aimed at making the student an active, reflective entity, creator of their own learning and knowledge. This BPL seeks in students the acquisition of abilities, attitudes, and skills. The role of the teacher is to guide and guide processes to interact in complex events that require it, since students have to adopt the condition of researcher and reflective, capable of proposing solutions to problems. Traditional education had important traces on the part of its teaching staff, the way of giving their classes was totally lectures, where the student only listened and then repeated, being a totally passive and only receiving entity (Leon et al., 2019). 
Currently, in parts the education sector establishes a certain standard evaluation model, where in some way the spontaneity of the students is avoided by giving them specific contents that limit their imagination (Terrones Aragón, 2018). In this regard, it is mentioned that the current situation in the teaching system is very real, where several thinkers and researchers question the permanence and application of traditional learning, the updating is not reflected, especially by the students. Teachers who refuse to experience the new trend in education (García, 2021). The implementation of the PBL contains structures that allow directing and organizing the work, so there are pillars and phases, which could be considered as implementation stages, considering it a guide to use the methodology, in which three phases can be mentioned: Presentation and design, research - action and evaluation. This structure allows the teacher and the student to follow a route that makes it possible to efficiently meet the objective set in terms of acquiring a satisfactory result, as seen in Figure 1, where the sequence to perform the PBL is described.

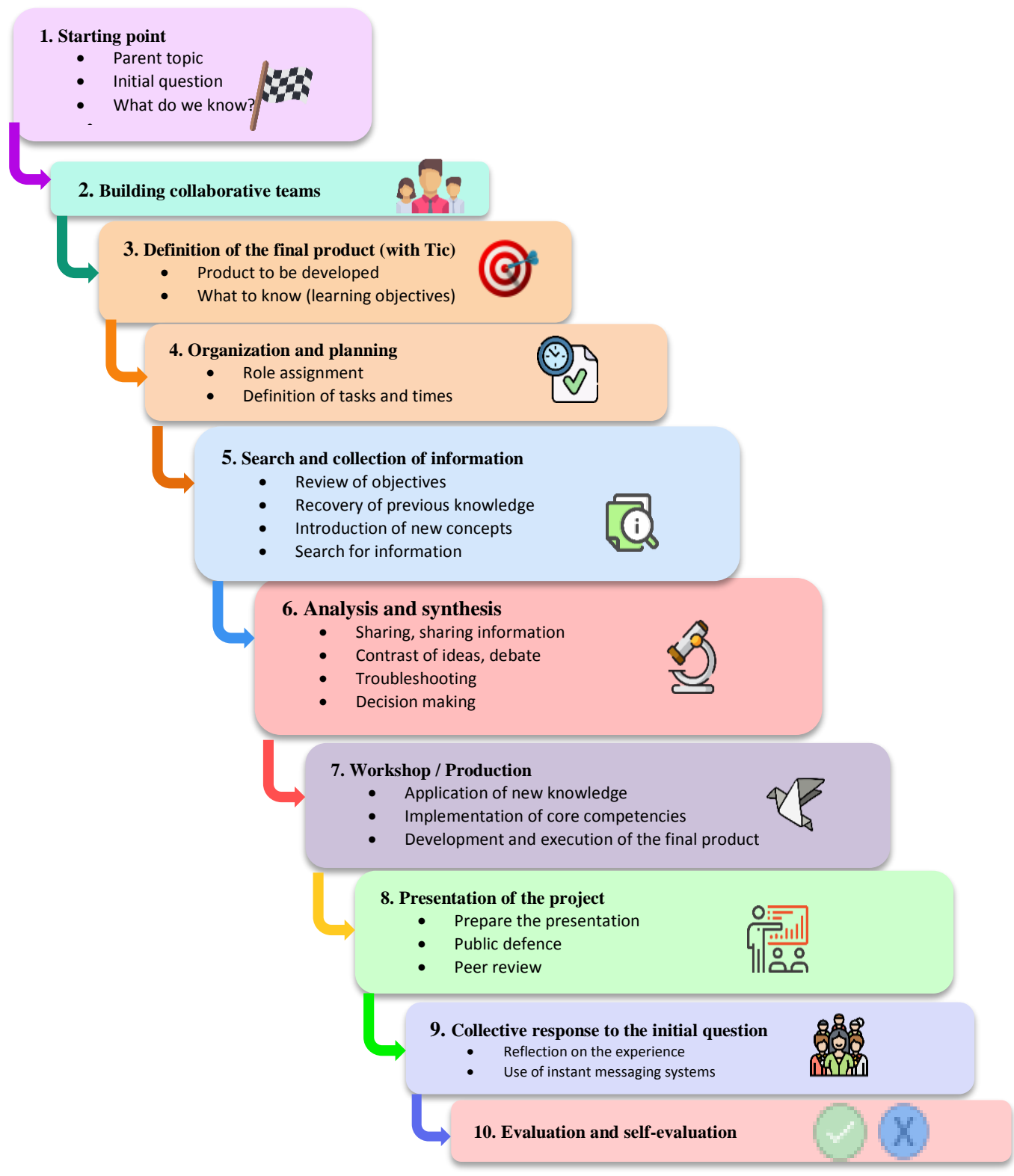

Figure 1. Steps for the construction of PBL Source: Alberto Valdés Guada

Guerrero, J. A. A., Moreira, J. A. M., Zambrano, M. J. Z., Rivas, F. E. C., \& Pilligua, M. L. B. (2022). Project-based learning and its contribution in virtual education. International Research Journal of Management, IT and Social Sciences, 9(1), 10-18. https://doi.org/10.21744/irjmis.v9n1.1973 
The diagram shows the steps to create an BPL, each of these is detailed below, considering its application in the Sebastián Muñoz Educational Unit:

1) Point. - It is the initial phase, in which the teacher creates a space for dialogue with the students, applying thought routines, in order for them to identify the topic and the problem on which they will develop their work.

2) Collaborative team formation. - It is at the time that the teacher uses to create the work groups, the selection mode can be established by the teacher or agreed by the participants.

3) Definition of final product. - This step allows the student to know the product they are going to obtain, the important data they need to know and the learning objective of the activity to be carried out.

4) Organization and planning. - In this phase, each group, with the teacher's guidance and guidance, will organize to define the roles, analyze the activities that they are going to carry out, the requirements and memories that they must have to fulfill the objective.

5) Search and collection of information. - It is important that students remember essential contents of the subjects that are directly related to the type of research, likewise it is necessary that in this phase the necessary and specific information of what it is intended to know is collected, always maintaining the idea of the objective Learning.

6) Analysis and synthesis. - It is a part of the project, which is considered essential, in this step an analysis of the contents of the research is carried out, among the members of the team they initiate a debate, share ideas and opinions where the professor maintains his condition of moderator or guide, finally this phase is concluded with decisions that have been agreed upon by the work team and made clear to the teacher.

7) Workshop / production. - Once the ideas have been organized and the conclusions generated, a document is created and results and procedures are checked, to finally put into practice the construction of new knowledge.

8) Presentation of the project. - It is a part of the project in which the work team prepares its presentation, this allows to disseminate the results before the educational community, making an exhibition of the acquired learnings and submitting their work to public opinion, this exhibition will be given in an organized way in spaces such as fairs, open houses or invitations in other educational establishments.

9) Collective response to the initial question. - The results that have been obtained with the exposure to the educational community will serve to create a space for reflection among those who make up each work team, this will allow them to identify negative and positive aspects in order to strengthen themselves and offer a greater effort in work later.

10) Evaluación y autoevaluación. - En realidad, una de las características del APB es de evaluar el proceso de la actividad, la participación y reflexión de los equipos de trabajo de manera colectiva e individual; si embrago es necesario aplicar tres tipos de evaluación, conocidas estas como heteroevaluación, coevaluación y autoevaluación.

It is pertinent to identify innovative aspects on which teachers are based for the application of knowledge, aspects that allow to attract the attention of students, considering not only communication tools and technology, but also the management of emotional situations that involve and motivate collaborative work (Pradas, 2017). To verify that the PBL is applied in virtual education, a survey was applied to 100 high school students from the Sebastián Muñoz Educational Unit where it was asked if the teachers applied the PBL methodologies in virtuality, shown in table 1.

Table 1

Application of the BPL methodology

\begin{tabular}{lcc}
\hline \multicolumn{1}{c}{ Variables } & Students & Percentage (\%) \\
\hline Yes, it was applied & 50 & 50 \\
Did not apply & 20 & 20 \\
It was applied on some occasions & 30 & 30 \\
\hline
\end{tabular}

As can be seen, there is $20 \%$ that do not apply the methodologies and $30 \%$ that in some cases use it, noting that approximately $50 \%$ of teachers do not use it in the teaching-learning process. Assessing the influence on the assimilation of knowledge in the pandemic stage and connectivity, the result was what is shown in table 2, where the lack of connectivity due to a deficient technological resource was considered. 
Table 2

Influence of the assimilation of knowledge due to lack of connectivity and deficient technological resources.

\begin{tabular}{lcc}
\hline \multicolumn{1}{c}{ Variables } & Students & Percentage (\%) \\
\hline Sí & 90 & 90 \\
No & 10 & 10 \\
\hline
\end{tabular}

As can be seen, there is $10 \%$ who assimilated the knowledge through virtuality during the health emergency and $90 \%$ of the students considered that they did not achieve significant learning due to lack of technological resources. To know if the BPL was significant in academic development, the result of the survey applied was what is shown in figure 2.

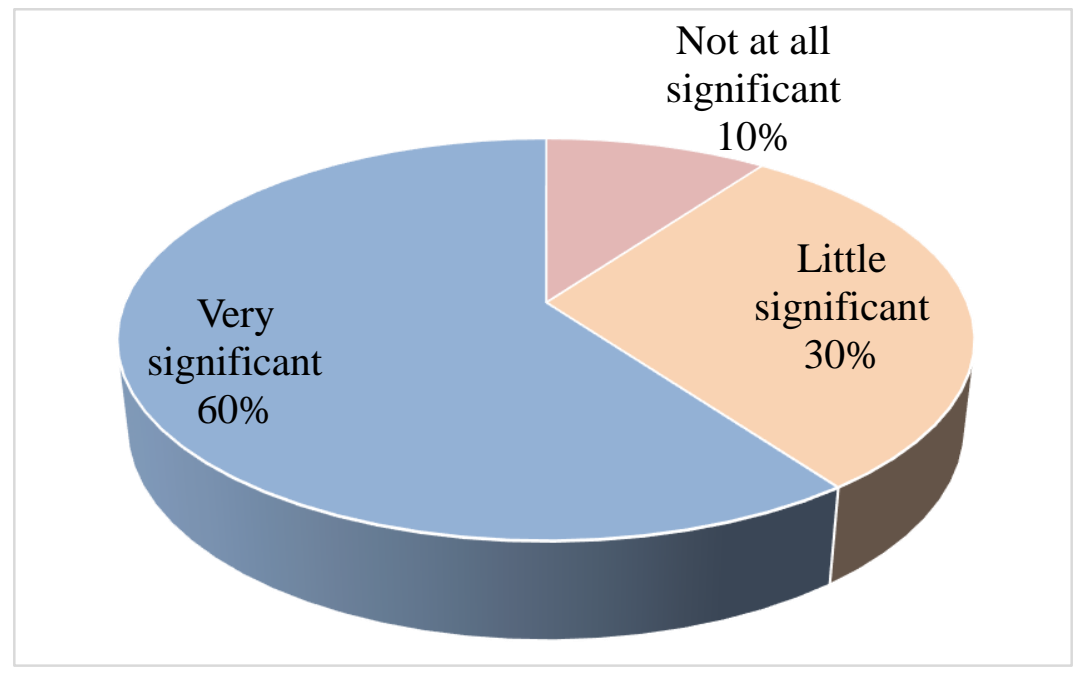

Figure 2. Meaningful learning for academic development with the use of PBL Source: Student survey

The graph shows that $10 \%$ considered the contribution made by the BPL in academic development to be not significant at all and $30 \%$ believe that it is not significant, noting that $60 \%$ of those surveyed consider the use of this methodology to be very significant. The lack of economic resources, health problems, migration and the distancing between sectors of the community, are factors that have also influenced the education gap for a large percentage of students, being part of the statistics of students with unfinished education, which implies a low level of knowledge in the use of active methodologies such as PBL as well as the effectiveness of the application of the method by teachers (Khan \& Smith, 2020; Laurencin \& Walker, 2020).

\section{Conclusion}

The application of the BPL methodology from the study of virtual education, had as a result that the application was favorable in students who presented adequate connectivity, facilitating interaction between students and teachers with accessibility to technology. Not all students in the community had the opportunity to continue their studies through virtuality due to lack of connectivity, affecting their academic performance (Ergun et al., 2007; Batt \& Purchase, 2004).

Guerrero, J. A. A., Moreira, J. A. M., Zambrano, M. J. Z., Rivas, F. E. C., \& Pilligua, M. L. B. (2022). Project-based learning and its contribution in virtual education. International Research Journal of Management, IT and Social Sciences, 9(1), 10-18. https://doi.org/10.21744/irjmis.v9n1.1973 
Conflict of interest statement

The authors declared that they have no competing interests.

Statement of authorship

The authors have a responsibility for the conception and design of the study. The authors have approved the final article.

Acknowledgments

We are grateful to two anonymous reviewers for their valuable comments on the earlier version of this paper. 


\section{References}

Anastakis, D. J., Regehr, G., Reznick, R. K., Cusimano, M., Murnaghan, J., Brown, M., \& Hutchison, C. (1999). Assessment of technical skills transfer from the bench training model to the human model. The American journal of surgery, 177(2), 167-170. https://doi.org/10.1016/S0002-9610(98)00327-4

Batt, P. J., \& Purchase, S. (2004). Managing collaboration within networks and relationships. Industrial marketing management, 33(3), 169-174. https://doi.org/10.1016/j.indmarman.2003.11.004

Borbor, CLN, \& Suárez, PCM (2021). Characterization of project-based learning to strengthen entrepreneurial skills. Knowledge Pole: Scientific-professional magazine , 6 (3), 2482-2499.

Borja, NL, \& López, LEV (2017). Project-based learning and academic performance of the Pasa Educative Unit students. Digital Science, 1 (2), 52-65.

Bottle Nicolás, AM, \& Ramos Ramos, P. (2019). Action research and project-based learning. A bibliographic review. Educational Profiles , 41 (163), 127-141.

Carbonnel, A., Ruz, D., Osorio, A. M., \& Hernández, C. (2019). Modelo pedagógico de educación científica escolar. Innovación social en localidades rurales. Perfiles educativos, 41(166), 58-74.

Ergun, Ö., Kuyzu, G., \& Savelsbergh, M. (2007). Shipper collaboration. Computers \& Operations Research, 34(6), 1551-1560. https://doi.org/10.1016/j.cor.2005.07.026

Escobar, M. Á., \& Lewin, MA (2018). Project-based learning: an alternative for the Waorani community in Ecuador. Inclusiones Magazine , 59-74.

Gámiz-Sánchez, V. M. (2017). ICT-based active methodologies. Procedia-Social and Behavioral Sciences, 237, 606612. https://doi.org/10.1016/j.sbspro.2017.02.018

García, O. B. (2021). Innovaciones metodológicas con TIC en educación. Dykinson.

Khan, M. A., \& Smith, J. E. M. (2020). "Covibesity," a new pandemic. Obesity medicine, 19, 100282. https://doi.org/10.1016/j.obmed.2020.100282

Laurencin, C. T., \& Walker, J. M. (2020). A Pandemic on a Pandemic: Racism and COVID-19 in Blacks. Cell systems, 11(1), 9-10. https://doi.org/10.1016/j.cels.2020.07.002

Leenders, R. T. A., Van Engelen, J. M., \& Kratzer, J. (2003). Virtuality, communication, and new product team creativity: a social network perspective. Journal of Engineering and technology management, 20(1-2), 69-92. https://doi.org/10.1016/S0923-4748(03)00005-5

León, W. M., Carranza, L. S., \& Sánchez, C. P. (2019). El aprendizaje basado en proyecto: Realidad y perspectivas. Journal of Science and Research: Revista Ciencia e Investigación. ISSN 2528-8083, 4(4), 22-33.

López Miller, ZE (2016). Project-based learning and the academic performance of the students of the Pasa Educative Unit (Master's thesis).

Mesmer-Magnus, J. R., DeChurch, L. A., Jimenez-Rodriguez, M., Wildman, J., \& Shuffler, M. (2011). A meta-analytic investigation of virtuality and information sharing in teams. Organizational Behavior and Human Decision Processes, 115(2), 214-225. https://doi.org/10.1016/j.obhdp.2011.03.002

Mizrahi, T. (1984). Managing medical mistakes: ideology, insularity and accountability among internists-intraining. Social science \& medicine, 19(2), 135-146. https://doi.org/10.1016/0277-9536(84)90280-6

Moya, E. C. (2017). Using Active Methodologies: The StudentśView. Procedia-Social and Behavioral Sciences, 237, 672-677. https://doi.org/10.1016/j.sbspro.2017.02.040

Muñoz-Repiso, AGV, \& Gómez-Pablos, VB (2017). Project-Based Learning (PBL): evaluation from the perspective of Primary Education students. Journal of Educational Research, 35 (1), 113-131.

Pachay-López, M. J., \& Rodríguez-Gámez, M. (2021). La deserción escolar: Una perspectiva compleja en tiempos de pandemia. Polo del conocimiento, 6(1), 130-155.

Pari, YRC, Puma, MI, \& Ramos, CB (2021). Project-based learning and its impact on the achievement of professional competencies in times of pandemic for students of the Professional School of Education of UNAMAD - 2020. Latin Science Multidisciplinary Scientific Journal , 5 (3), 3048-3061.

Pradas, S. (2017). Neurotecnología educativa. Claves del uso de la tecnología en el proceso de aprendizaje. ReiDoCrea, 6(2), 40-7.

Rayuwati, R. . (2020). How educational technology innovates distance learning during pandemic crisis in remote areas in Indonesia?. International Research Journal of Management, IT and Social Sciences, 7(6), 161-166. https://doi.org/10.21744/irjmis.v7n6.1032

Sagardía, AE, Caño, L., \& Madrazo, AA (2020). Mathematical competence in Primary Education through projectbased learning. Mathematics Education, 32 (3), 241-262.

Guerrero, J. A. A., Moreira, J. A. M., Zambrano, M. J. Z., Rivas, F. E. C., \& Pilligua, M. L. B. (2022). Project-based learning and its contribution in virtual education. International Research Journal of Management, IT and Social Sciences, 9(1), 10-18. https://doi.org/10.21744/irjmis.v9n1.1973 
Solís, P. M. C., \& Tacuri, H. J. L. (2021). El Aprendizaje Basado en Proyectos desde la perspectiva docente. Mamakuna, (17), 49-56.

Sudarmo, S. (2020). Leadership and human resource management: response to the COVID-19 outbreak . International Research Journal of Management, IT and Social Sciences, 7(6), 167-174. https://doi.org/10.21744/irjmis.v7n6.1033

Terrones Aragón, M. (2018). Aplicación del aprendizaje basado en proyectos para fomentar la creatividad en la asignatura de Tecnología. Ice. 